\title{
DEATHLY NARRATIVES
}

\section{Theorising "reo-rientation" for language revitalisation discourses}

\author{
Vincent Ieni Olsen-Reeder*
}

\begin{abstract}
Death narratives are common in literature on the Māori language. While there is a place for language death, such a strong focus on death may be limiting our scholarship. Conclusions drawn from such approaches may risk overlooking key information about language health, and this could pull the scholarship further away from reliable language health conclusions. This article discusses the need to offer space to new language conversations in contemporary times. The most recent published scholarship in the Māori language discipline is examined to support a new discussion. Using the taxonomy of ethnolinguistic vitality (Giles, Bourhis, \& Taylor, 1977) to collate recent research, it is posited that the death narrative might no longer be relevant in and of itself, and that a reorientation of the discourse may be needed. By removing the deficit and death lens from the conversation, alternative, and arguably more helpful, analyses of the state of the language might be obtained. This allows for a deeper understanding of our language revitalisation efforts.
\end{abstract}

\section{Keywords}

language revitalisation, te reo Māori, sociolinguistics, language policy, ethnolinguistic vitality, language death

* Ngā Potiki a Tamapahore, Ngāi Te Rangi, Ngāti Pūkenga, Ngāti Whakaue. Lecturer, Te Kawa a Māui, Victoria University of Wellington, Wellington. Email: Vini.Olsen-Reeder@vuw.ac.nz

DOI: 10.20507/MAIJournal.2018.7.2.7 


\section{Introduction}

The Value of the Māori Language: Te Hua o te Reo Māori (Higgins, Rewi, \& Olsen-Reeder, 2014) provided an analysis of Māori language revitalisation over a 25 -year period since the language was entrenched in law through the Māori Language Act 1987, since replaced by Te Ture mō Te Reo Māori 2016: The Māori Language Act 2016. In this publication, Higgins and Rewi (2014) question the presence of language deficit in research, lamenting that:

research related to Māori language is primarily positioned from a deficit position. It is framed and reported in a manner that it is dying, and this mentality has compounded our fixation with . . . an effort to reverse this decline. (p. 30)

A key catalyst for this article was the perceived need to embark on a conversation about language deficit, to examine the discourse of language death in language research, and to determine whether such a position is true and necessary.

Through reviewing the movements of the last five years since The Value of the Mãori Language was published, this article argues there may be a need to reorientate (or "reorientate", as the title suggests) the language we use in language health discussions. Where the rhetoric used in te reo Māori language health research is typically of deficit and language death, this article argues that there is a time and place for language death, but it may no longer fit as a single discourse for discussing issues pertaining to the language. The events of the last half decade suggest that a number of different approaches to the dialogue are necessary, and that a perpetuation of the language death rhetoric may present a barrier to understanding the real state of the Māori language todaywhich has implications for our knowledge of language issues.

In order to bring this information together in a coherent format, I use a well-known sociolinguistic taxonomy in language vitality research, ethnolinguistic vitality (EV) (Giles, Bourhis, \& Taylor, 1977). This approach allows the many facets of language health to be discussed in a cohesive manner, presents a counter-narrative that challenges the intent behind the deficit focus in the literature, and argues for more diverse approaches to discussing language health.

\section{A deathly narrative}

At the outset it is important to qualify and critique the presence of language death as a narrative in the literature, and position this article as an effort to challenge language death and deficit as a primary mode of research, while not denouncing it as a "wrong" approach altogether.

As a construct, death is present in our most seminal literature on language revitalisation (e.g., Crystal, 2002). Pioneers of the field, such as Fishman (1991, 2000, 2012) and Spolsky $(1986,2004,2009,2012)$ have focused extensively on reversing language shift, and on a spectrum stretching from language death to revival. So too is language death a key part of some of our language health measures. UNESCO (2017), for example, uses language extinction and danger as a key parameter for labelling less-dominant languages around the world. Sociolinguists inherently believe no language is more important than another, thus all languages are deserving of dedicated attention. Politically, sociolinguists feel more obligated to languages where threatened states are brought about by unnatural causes such as colonisation and assimilation, which is often the case (Hinton, Huss, \& Roche, 2018). Communities care deeply about the languages of their society, and thus of course feel a natural obligation to ensure their languages thrive. Facing these situations means a fixation on death from within relevant disciplines is not unfounded. After all, languages do die, and people do care about that. 
Language death conversations are important in the interests of being realistic, of understanding risk and of planning effectively to ensure death does not eventuate.

The parameters of death in the literature are potentially unhelpful though, in the sense that they are almost impossible to shift from. To return to the above example, UNESCO's measure (ranging from vulnerable to extinct) ensures languages stay relatively stagnant within differing definitions of deficit and death. There doesn't appear to be a mechanism for marking languages as healthy or safe-an option for peeling back the tarnish of the brush. It seems reasonable to suggest that such a strong penchant for the death narrative limits the ability of practitioners, and those who invest in such scholarship, to ever progress a line of thinking that shifts away from deficit and death. Instead, language states are eternally condemned to one death state or another, but never allowed to be a living one. Totally ignoring the deathly end of the spectrum would, of course, not be ideal for our languages, so it makes sense that it is recognised in the literature. It is the deficit of death that is the problem-that the spectrum totally ignores life, development or improvement. This seems to do little to develop those languages, or the scholarship that concerns them.

With respect to te reo Māori, it is generally accepted that at some point the language became close to dying (Benton, 1986, 1991). Just how close the language came to death is difficult to prove irrefutably, but as Richard Benton (1986) notes, some had deemed the state irreversible even in the 1960s. Biggs (1968) himself notes that statistics of the time are "few, not easily comparable, and not all reliable" (p. 75). The accuracy of "irreversibility" is difficult to truly quantify. What we can say, however, is that the work of Benton (alongside Nena Benton) became the first evidence of language shift from Māori to English, and such "landmark" work inspired great amounts of work to tempt reversal of that situation (see Reedy, 2000, p. 158). That work has been intense, long-lasting and well documented by others in the literature, so is not discussed here (see Ka'ai, 2017).

It is important to note where language death conversations have taken place with regard to te reo Māori. Language death can be an aggressive tool to critique revival work, and those carrying it out (e.g., Moon, 2018). Others come from a more concerned perspective. A recent article about the health of te reo Māori in Ōtākou (Pōtiki, 2017) carries death in its title: "Ko Hurumutu te Reo" (The Language Is Dead). In an earlier article, Pōtiki (2015, p. 172) documents the actual death of the last native Māori speaker of her region-proof enough of language death for any sociolinguist. Pōtiki (2017) reasons about her approach to a language death narrative (my translation follows):

Me te mea nei he ngākau e mamae rawa ana ki te whakarongo ki tēnei mea, te matenga o tō rātou reo ki te kāinga. Nā, ko tāku e kī atu nei, ehara i te mea he kōrero whakaiti. Engari kē, he kōrero hei akiaki i ōku whanaunga ki te whakaora anō i tō mātou reo. (p. 339)

It's as if hearts break when they hear me say it, that our language is dead here at home. But what I'm trying to say isn't a denigration. Rather, it's a statement designed to urge my relations to revitalise our language.

This statement shows a clear connection between reality and linguistic definitions of language death. In this example, attaching the author's reality to the idea of death seems quite apt. Also of note is the author's connection to "urge" people to action. In this way, deficit narratives appear to be used to provoke positive reaction. Kawharu's (2013) edited collection of essays, Maranga Mai! Te Reo and Marae in Crisis?, examines language death issues in $\mathrm{Te}$ Tai Tokerau. Kawharu includes a call to action in the volume's title: "Maranga Mai!" means "wake up!" When used in these ways, the shock of language death seems to stand as a motive to spark action in others. Nevertheless, these are 
still to some degree illustrative of the presence of deficit in the literature.

MacLeod (2014) too recognises the call-toaction sentiment behind such statements but does not seem convinced this kind of dialogue is helpful (my translation follows):

Tērā tētahi kōrero i kapohia atu e aku taringa i ngā tau nei, e mea ana, 'Tukuna taku reo kia mate rangatira, koi tukuna kia mate taurekareka noa.' Tumeke ana au i tērā kōrero me te whakaaro iho, 'e hika mā, nō hea au e whakaae kia mate i a au te reo nei. (p. 149)

There's a statement I've heard over the years that says, "Let my language die a noble death, don't let it die a slovenly death." That assertion shocks me and I think, "Wow, there's no way I'd agree to let this language die."

It is good for the action of Māori language communities to be based on the research language scholars carry out. However, if Māori language research is compounded within the notion of language death, then it makes sense to suggest there are no other avenues through which action can be inspired. If action is only inspired through fear of death, then the attitudes and beliefs of our communities will struggle to move away from it. Altogether, this seems unhelpful to revitalisation, where the overall objective is to inspire language change within our speaker communities.

To summarise then, language death does seem to be a necessary part of the language conversation for some communities, but is not necessarily conducive to helpful language action. "Fixating" on deficit does seem to ensure we follow a path of action and research that risks equally deficit products. This seems problematic for extending our understanding of language health.

\section{Ethnolinguistic vitality-a taxonomy}

In attempting to provide a departure away from language death in scholarship, Giles et al.'s (1977) EV taxonomy is adopted here. In their work, Giles et al. (1977, p. 308) provide a structural analysis in which they outline the many "situational variables operating in a given intergroup situation" (p. 308). In this design, they privilege three variables believed to be pertinent in maintaining vitality for an ethnolinguistic group: demography, institutional support, and status (Giles et al., 1977, p. 309). Each variable has a number of relevant subgroups, examples of which include population concentration (demography), government assistance (institutional support) and language prestige (status). It is upon this basis that inferences about the state of a language group, and therefore its language, can be made.

This is not the only taxonomy available but it does provide an appropriate avenue for exploration in this article. It should be noted here that there is a difference between EV as a taxonomy for research and ethnolinguistic vitality as a more general descriptor (a fact well documented by Ehala, 2010) present in Māori language research (e.g., Te Huia, 2017). Few have utilised the EV taxonomy with respect to te reo Māori, although there is the odd instance of it in the literature (e.g., Ngaha, 2013).

Scholarship pertaining to the Māori language here is limited to a scope between 2014 and the present as far as is possible. This is to help substantiate the claim that death and deficit are no longer adequate for our most recent conversations around language health. The year 2014 was chosen because that was the year The Value of the Mãori Language was published. Older scholarship is still referenced, particularly seminal publications, or where absences risk plagiarism. For te reo Māori in particular, the three variables are used to offer a basis on which the discussion of current Māori language vitality can be discussed. The subgroups are not particularly covered below, due to the desire to 
align to scholarship that is as recent as possible, and not all subgroups have recent literature to evidence them.

\section{Demography}

Of the demography variable, Giles et al. (1977) state that it is defined in terms of "the sheer numbers of group members and their distribution throughout the territory" (p. 309). This includes aspects such as population, spread, and immigration and emigration. To put this in context for te reo Māori, demography is the total population of Māori speakers in New Zealand that is commonly used to discuss the vitality of the language. These numbers are used widely to discuss language health at a national level, and frequently pitched as indicators of language decline. Statistics New Zealand (2017), for example, shows a decline in Māori speakers of te reo from $24.97 \%$ in 1996 to $21.31 \%$ in 2013. In another study, however, a subgroup of Statistics New Zealand called Te Kupenga (2014) noted that $55 \%$ of Māori adults could speak te reo in 2013, an increase from $42 \%$ in 2001. The validity and appropriateness for comparison of these figures has been a concern to scholars and statisticians alike (Bauer, 2008; Statistics New Zealand, 2014). These concerns have not stopped their use in the literature, although some studies try to make cautious sense of the numbers in lieu of other statistical data (Hutchings et al., 2017; Olsen-Reeder, 2017b). If populations of speakers are stacked against the large numbers of the dominant language group, and its dominant language, a binary pairing results, pitching the idea that Māori language is in decline for its inability to match the progression and trend of English. In this manner, Māori will be deemed threatened until such a time when the population of Māori speakers equals or surpasses those who speak English. This seems an exercise in futility: there is no magic number of speakers a language must reach before it may be pronounced safe. Since there is no such number, binary pairings are not always entirely helpful.

Speaker populations are frequently matched with levels of proficiency (e.g., Te Kupenga, 2014), despite these being questioned by some for their reliability (Higgins \& Rewi, 2014, pp. 20-21). This match is used to show the small number of native speakers of Māori, and the large number of second language learners. It also shows that most native speakers belong to older generations. These are touted as a sign of language decline, presumably because younger, second language learners are assumed to be less fluent. However, this is not necessarily the case, as "high oral competency of individuals does not automatically mean that conversations between whānau members would be sustained" (Ormsby-Teki, Timutimu, Palmer, Ellis, \& Johnston, 2011, p. 89). As Christensen (2001) notes, language use is undeniably important in language revival. As far as use is concerned then, native older speakers do not guarantee any more to revival than second language learners do. Others support this statement (e.g., Bauer, 2008; Karetu, 2014; Olsen-Reeder, 2017a). It is entirely possible then that greater contributions to language vitality can come from second language learners than from fluent speakers. Nevertheless, proficiency demographics reinforce the notion that fluency is the most primary measure of language health and contribution to the cause, despite evidence to the contrary.

One last extension to demographics must be commented on here, the Māori Language Rate. According to Te Puni Kōkiri (2008, p. 18), the Màori Language Rate is in decline. This measure has not been revisited recently, although a limited amount of discussion on native speakers of Māori and their ages is contained in Olsen-Reeder (2017a). In essence, the Māori Language Rate decline shows that the rate of Māori babies being born is growing faster than the rate of Māori speaking babies who are of Māori descent, and who are being raised as first language speakers of Māori. The measure is seen in relation to intergenerational 
transmission, which is understood to be the pinnacle measure of language health. Most of our language speakers, however, are second language learners (Higgins, Rewi, \& OlsenReeder, 2017, p. 7). They thus are learning later on in adult life. It is also unclear if the measure includes babies being born as native speaking bilinguals. It would be a more useful tool if such trends could be traced over time.

Dedicated studies that measure different groups of people in the Māori language community allow for a diverse conversation about population numbers to be had. Reese et al. (2018) concluded that in their study of 6,327 children and their mothers, "Māori language regeneration is occurring in the new generation of New Zealanders", albeit "in the context of English language acquisition" (pp. 356-357). In Te Ahu o te Reo Māori, a regionally based study, $85 \%$ of 448 adults interviewed had at least some te reo Māori spoken in the household (Hutchings et al., 2017, p. 12). In the Te Kura Roa research programme (Higgins et al., 2017, p. 2), $30 \%$ of respondents were native speakers or second language learners with a high proficiency in the language. These kinds of numbers, when considered as individual contributions to the landscape of te reo, paint a picture of language health that shows an increasing amount of Māori language acquisition in some families, including ones who might be deemed non-Māori speaking ones. They show a spread of Māori speaking households throughout the country, and that there is some continuity in the coverage of speakers who reside around the country. Lastly, a third of active Māori speakers have an excellent command of the language. This is a very different picture of health to that painted by the other numbers shown above-one that incorporates several different kinds of communities who are contributing to language health. One population-based statistic for the whole nation is supported by one of the more specific studies, which should provide confidence in that number. According to the Māori Language Advisory Group (MLAG, 2015, p. 75),
$2.6 \%$ of households in New Zealand use te reo Māori as the main language of communication. Hutchings et al. (2017, p. 12) corroborate this number, placing te reo speaking household in their study at $3 \%$.

In addition to population and proficiency, the movement of Māori speakers, mostly to and from Australia, is an important feature of Māori language demographics because of the sheer size of the numbers involved. Although published prior to the 2014-2018 scope of this article, Hamer's (2011) work is crucial in gaining an understanding of the trans-Tasman movement of te reo, which contributes to its overall vitality within the confines of New Zealand. It is crucial because this movement is virtually absent in Māori language literature (Hamer, 2011, p. 46). There is an approximate population of 48,777 speakers of Māori in Australia, $23.7 \%$ of the total population of Māori living in Aotearoa (Hamer, 2011, p. 52). Of these, according to Hamer (2011), approximately $15 \%$ use te reo as a home language. Some may be tempted to tout this as a contributor to a decline in language health because these people do not reside in the country. Indeed, Giles et al. (1977) included this sub-variable to support the idea that a language group's health is judged based on their physical presence in their traditional, regional homeland. However, in a time where movement is increasing and easier than ever before, it might be the case that this language group have much to offer back to the community they, or their parents or grandparents, might have left. The opportunities to examine the language vitality that trans-Tasman migration provides have already been noted by Higgins (2014), who states (my translation follows):

He tokomaha [te hunga] kei Ahitereiria o tōku nei reanga kua kaumātua, kua mutu te mahi moni, ā, i tipu mai i roto i te reo Māori.... Kei te pai tonu hoki ō rātou reo, ahakoa te roa e noho mai ana i reira. Ko tētahi āhuatanga hoki kua kite au i reira. Ko aku uri i tipu mai 
i te reo, kāre anō kia rerekē ake te tangi, te mita, te whakatakoto o ngā kupu. ... Ko te reo o ō mātou koroua, ngā kupu, kua kore kē nei e whakamahia i tēnei wā, ko te rere, ko te mita - te mutunga mai o te reka, o te ātaahua. (p. 284)

There are many people in Australia of my generation who have retired, and they've grown up immersed in the Māori language... . Their language skills are still good, although they've lived there for a long time. Something I've seen there, in my relations who grew up with the language, the inflection, tone and structure hasn't yet changed. . . . It's the language of our grandparents, words that are no longer used now, the speed and tone-it's incredibly sweet and beautiful.

Here, the absence of these older generations in New Zealand has caused them to exist in a language silo. Although this might have eventuated in language shift for themselves personally, they have managed to maintain their passive knowledge of te reo Māori from a time when they potentially spoke and lived as monolingual Māori speakers. This kind of language use is unique and worthy of recognition. It can be argued that these people still have much to contribute to the vitality of te reo Māori, if methods can be found to allow them to do so.

\section{Institutional support}

The second variable in the $\mathrm{EV}$, institutional support, "refer[s] to the extent to which a language group receives formal and informal representation in the various institutions of a nation, region or community" (Giles et al., 1977, p. 309). Included as subgroups of this theme are the media, education and government services. Most recently, it is the orientation of legislation that has caused an astronomical amount of change in the Māori language community, which is the focus of attention here.
As previously mentioned, the Māori Language Act 1987 is now defunct, and so is not discussed here. Arguably, the biggest legislative change in Māori language history occurred with the enactment of its successor, Te Ture Mō Te Reo Māori 2016. An account of how this law came to be is given below.

In 2010, the then Minister of Māori Affairs Hon Dr Pita Sharples established a review panel to overhaul the Māori language sector named Te Paepae Motuhake (Te Puni Kōkiri, 2011). This group was charged with reviewing the sector, and providing recommendations to the Minister for improvement. Their findings recommended:

1. Establishing a Minister for te reo Māori

2. Establishing a body to govern the sector, to be called Te Mātāwai

3. Establishing rūnanga reo ā-iwi

4. That the key objective be intergenerational transmission

5. That revitalisation objectives at the macro level be led by iwi. (Te Puni Kōkiri, 2011, p. 7)

The outcome of this review panel also led to a new Māori Language Strategy (Te Puni Kōkiri, 2014), which replaced the 2003 version. This strategy, however, was met with concerns from the Māori language community. These concerns seem to revolve around a lack of detail and (perhaps humorously) a lack of strategy specifics to ensure its goals could be achieved (MLAG, 2015). This strategy is still available but does not seem to be discussed now, so no longer appears to be in effect. This is possibly due to the establishing of a new Māori Language Act and Te Mātāwai (discussed below). Because of the concerns about, and criticisms of, the strategy, in 2015 the incoming Minister of Māori Development, Te Ururoa Flavell, announced a second review panel, the MLAG, to bring the findings of Te Paepae Motuhake to life, and to address concerns raised by the Māori language community about initial policy documents. 
After nationwide consultation, the MLAG tabled a report: Te Whare o te Reo Mauriora (2015). The report is organised by the key components of a methodological whare called " $\mathrm{Te}$ Whare o te Reo Mauriora" as a way to understand the thinking behind the recommendations that MLAG made. The MLAG's report would become the basis for nationwide language policy shifts. These shifts had two key outcomes: legislative change and directives for nationwide language policy and planning.

As an immediate outcome of the report, a new bill was tabled to repeal and replace the Māori Language Act 1987. Te Ture Mō Te Reo Māori 2016 was passed into law in April 2016. It is one of only two pieces of legislation in New Zealand to be heard and enacted in te reo Māori, with the Māori language version taking legal precedence over the English translation. Towards the close of 2016, Te Mātāwai was established as a fully independent crown authority. By early 2017, its membership had been solidified.

As mentioned before, the second outcome from Te Whare o te Reo Mauriora was a recognition of the importance of language planning, top-down and down-up. To this end, a body of language planning and policy experts now travel the length and breadth of the country to teach language planning skills to the Māori language community. This body, called Te Kura Whakarauora, provides an opportunity for the grassroots to learn how to plan for te reo use in their homes, communities, workplaces and marae (Kohatu \& Roberts, 2016). At the time of writing, Te Kura Whakarauora had completed 16 weekend-long language planning and policy intensives between November 2015 and May 2018, catering to approximately 600 participants and their communities. The intensives are coordinated and run by those well-versed in the objectives of Te Mātāwai, which ensures that up-to-date and relevant information is seamlessly exchanged between the micro and macro levels of planning. One limitation of these intensives is that funding is obtained via contestable funding sources. This means that there is always a chance the funding will cease and with that the ability to deliver much needed language planning information to micro level communities.

Granted, Te Mātāwai has not been in effect long enough to make any inference about its success in a new direction of language revitalisation. What can be said, however, is that its establishment has forced the Māori language community to take more control of its domain, and this will require more concerted efforts from more members of that community into the future.

\section{Status}

According to Giles et al. (1977), "the status variables are those which pertain to a configuration of prestige variables... . The more status a linguistic group is recognized to have, the more vitality it can be said to possess as a collective entity" (p. 309). Within this third and final variable in the EV is a language status subgroup, which suggests that the more mana associated with a language group, the more mana the language will also possess.

The status variable leads us back to Te Mātāwai as the overarching governing body charged with providing strategic direction for the language. Where previous discussion encircled Te Mātāwai's entrenchment in legislation, this section discusses the position of Te Mātāwai and its status as a government authority. The status of Te Mātāwai, and thus the status the language has in the hierarchy of government, is explored here.

Te Mātāwai (2018) comprises 13 members. Seven members are iwi representatives, who are selected and managed by their respective collective. There are four representatives from education, broadcasting, urban centres and the community, respectively. The final two are ministerial appointments. This composition ensures coverage of iwi and pan-tribal Māori 
language membership. These members form the Maihi Māori, or the tangata whenua side of Te Whare o te Reo Mauriora (Te Mātāwai, 2018).

Of course, the tara iti is met with the tara whānui, the manuhiri space. This space is known as the Maihi Karauna (MLAG, 2015, p. 57). Having this side of the house present ensures that the Crown are not able to renege on their responsibilities to support the linguistic landscape of Aotearoa, but that authority ultimately rests with tangata whenua, the Maihi Māori. Parties within the Maihi Karauna include Te Aratuku Whakaata Irirangi Māori: The Māori Television Service, Te Māngai Pāho: New Zealand on Air and Te Taura Whiri i te Reo Māori: The Māori Language Commission.

Establishing Te Mātāwai will potentially raise the status of te reo Māori, but not in the traditional sense in which language status is discussed in the literature. Typically, language prestige is discussed in relation to the attitudes of the dominant language group (e.g., Albury, 2018; Nicholson \& Garland, 2010; Reese et al., 2018; Te Puni Kōkiri, 2010), or how much the dominant language group is willing to tolerate the presence of a minority language (de Bres, 2008). However, the status of te reo Màori is important in the realms of influence Te Mātāwai operates within. Inside Te Whare o te Reo Mauriora, all parties meet within the same sphere of hierarchy in the upper echelons of state operations. Many of the members of Te Mātāwai are also accountable to regional tribal clusters. In essence, this should provide opportunities for individual opinions at the grassroots level to be present in the highest spheres of government. With iwi representatives as the intermediary, there should be less distance between the needs of language communities and the directives of government to meet those needs. This is important to note with respect to language status-Māori are no longer reliant on government deciding how much status to award the language. Rather, communities themselves can influence how much status is awarded to the language. Autonomy is important, as May (2018) points out:

The issue of greater autonomy for minority language speakers that emerges from language rights' arguments also highlights the need for greater reciprocity and accountability among majority language speakers. In particular, it requires majority language speakers to extend to minority language speakers the linguistic privileges that they themselves take for granted. (p. 10)

The methodology of Te Whare o te Reo Mauriora is the most powerful tool the Māori speaking community has ever had in autonomously giving space for language status to eventuate in a top-down fashion. Of course, as Te Mātāwai is only newly established, so much of this is speculative. However, the potential for positive status shifts here is immense.

\section{Research reo-rientation}

As the above has shown, a reorientation of language narratives provides an alternative narrative to the omnipresent language death conversation. The legislation and research of the last half decade suggests a picture of language health very different to that painted in the past. It is from these findings that it is argued a move away from deficit narratives is thus appropriate and necessary to contruct a picture of language health. That is not to say language death has no role in our conversations, just that other aspects of the language spaces we work in are deserving of far more attention.

It is my feeling that language death is so present in the literature because it is tangible, known and defined. Extinction is finite and easily understood. After all, languages do die. It is also true that death is the same for any language - death is death. This means that cross-linguistic, pan-geographical conversations can be had in the literature that reinforce 
the complex realities languages undergoing revival are confronted with. Language revitalisation, however, is harder to define, impossible to predict and tough to measure. Discussions around the potential health of a language are difficult to present in the literature, and even harder to substantiate with evidence. The revival of one language tends to occur through processes different from those in the revival of another language, which means no language revival will look like another. It is harder to have cross-cultural and intra-geographical conversations about language revival. It is here that I think the pervasiveness of death and deficit originates from.

\section{Conclusion}

This article has outlined the prominence of language death in language revitalisation literature, and recounted scholarship pertinent to its rise as a primary narrative in Māori language revitalisation scholarship. Furthermore, it has used the EV taxonomy to collate the most recent scholarship from the field, and argued that language death as a deficit approach to our discourse is no longer fitting as a primary narrative.

As Higgins and Rewi (2014) have pointed out, te reo Māori has already been revitalised, based on the efforts of many over time. To use Fishman's term, "language shift" is ceasing or even ceased. The task now is to improve that health, and reverse that language shift to find a happy medium in use of both Māori and English. Death narratives do very little to move the Mãori speaking community towards this objective. Instead, the future must look to a paradigm shift in approach-towards a focus on the development of the language, not whether or not it even exists any more. While this rhetoric is still admissible in certain situations, there is enough recent academic evidence to warrant moving away from deficit approaches and narratives in research. Furthering the boundaries of Māori language research relies on moving past this narrative, and future language research needs to address this reality now in order to extend the scholarship of the discipline further and more clearly.

\section{Glossary}

Aotearoa

iwi

Maihi Karauna

Māori name for New Zealand; lit. "land of the long white cloud" tribe

the Crown responsibilities under the new Māori Language Act; lit. Crown bargeboard of a meeting house

Maihi Māori

Māori responsibilities under the new Māori Language Act; lit. Māori bargeboard of a meeting house

mana

manuhiri

Ōtākou

prestige, authority

guest

original name for Otago

rūnanga reo ā-iwi

tangata whenua

tara iti

regional language councils

Indigenous people of the land, Māori

smaller side of a meeting house

tara whānui

larger side of a meeting house

te reo Māori

Te Tai Tokerau the Māori language

Northland

whānau extended family grouping 


\section{References}

Albury, N. (2018). "If we lose their language we lose our history": Knowledge and disposition in Māori language acquisition policy. Journal of Language, Identity \& Education, 17(2), 69-84. http://doi.org/cvd8

Bauer, W. (2008). Is the health of te reo Māori improving? Te Reo, 51, 33-73.

Benton, R. (1986). Schools as agents for language revival in Ireland and New Zealand. In B. Spolsky (Ed.), Language and education in multilingual settings (pp. 53-76). Clevedon, England: Multilingual Matters.

Benton, R. (1991). The Maori language: Dying or reviving? Honolulu, HI: East-West Center Association.

Biggs, B. (1968). The Maori language past and present. In E. Schwimmer (Ed.), The Maori people in the nineteen-sixties (pp. 65-84). Auckland, New Zealand: Blackwood and Janet Paul.

Christensen, I. (2001). Ko te whare whakamana: Māori language revitalisation (Unpublished $\mathrm{PhD}$ thesis). Massey University, Palmerston North, New Zealand.

Crystal, D. (2002). Language death. Cambridge, UK: Cambridge University Press. http://doi.org/cvd9

De Bres, J. (2008). Planning for tolerability: Promoting positive attitudes and behaviours towards the Maori language among non-Maori New Zealanders $(\mathrm{PhD}$ thesis, Victoria University of Wellington, Wellington, New Zealand). Retrieved from http://hdl.handle.net/10063/687

Ehala, M. (2010). Refining the notion of ethnolinguistic vitality. International Journal of Multilingualism, 7(4), 363-378. http://doi.org/b3z9v3

Fishman, J. (1991). Reversing language shift: Theoretical and empirical foundations of assistance to threatened languages. Clevedon, England: Multilingual Matters.

Fishman, J. (Ed.). (2000). Can threatened languages be saved? Reversing language shift, revisited: A 21st century perspective. Clevedon, England: Multilingual Matters.

Fishman, J. (2012). Language maintenance, language shift, and reversing language shift. In T. K. Bhatia, \& W. C. Ritchie (Eds.), The handbook of bilingualism and multilingualism (2nd ed., pp. 466-494). Chichester, England: Wiley. http:// doi.org/cvfb

Giles, H., Bourhis, R. Y., \& Taylor, D. M. (1977). Towards a theory of language in ethnic group relations. In H. Giles (Ed.), Language, ethnicity and intergroup relations (pp. 307-348). London, England: Academic Press.

Hamer, P. (2011). The split totara: Te reo Māori and trans-Tasman migration. Te Reo, 54, 45-69.

Higgins, T. R. (2014). Kia ora tonu mō ake tonu e! In R. Higgins, P. Rewi, \& V. Olsen-Reeder (Eds.), The value of the Mãori language: Te hua o te reo Māori (pp. 269-290. Wellington, Zealand: Huia.

Higgins, R., \& Rewi, P. (2014). ZePA - Right-shifting: Reorientation towards normalisation. In R. Higgins, P. Rewi, \& V. Olsen-Reeder, V. (Eds.), The value of the Mãori language: Te hua o te reo Māori (pp. 7-32). Wellington, New Zealand: Huia.

Higgins, R., Rewi, P., \& Olsen-Reeder, V. (Eds.). (2014). The value of the Màori language: Te hua o te reo Māori. Wellington, New Zealand: Huia.

Higgins, R., Rewi, P., \& Olsen-Reeder, V. (2017). Ngā whakakitenga a Te Kura Roa: Whaibua [Report series]. Auckland, New Zealand: Ngā Pae o te Māramatanga.

Hinton, L., Huss, L., \& Roche, G. (2018). Language revitalization as a growing field of study and practice. In L. Hinton, L. Huss, \& G. Roche (Eds.), The Routledge handbook of language revitalization. New York, NY: Routledge.

Hutchings, J., Higgins, R., Bright, N., Keane, B., OlsenReeder, V., \& Hunia, M. (2017). Te abu o te reo: Te reo Māori in homes and communities-overview report. Wellington, New Zealand: NZCER.

Ka'ai, T. (2017). Great-grandfather, please teach me my language! Multilingua, 36(5), 541-563. http://doi.org/cvfc

Kawharu, M. (Ed.). (2013). Maranga mai! Te reo and marae in crisis? Auckland, New Zealand: Auckland University Press.

Kohatu, R., \& Roberts, T. (2016). Kura Whakaranora report 2016. Retrieved from http://www. tetaurawhiri.govt.nz/assets/Research/KuraWhakarauora-Eng2.pdf

MacLeod, J. (2014). He hua rānei tō te reo Māori mō ngā rā kei te heke mai? In R. Higgins, P. Rewi, \& V. Olsen-Reeder (Eds.), The value of the Māori language: Te hua o te reo Māori (pp. 141-150). Wellington, New Zealand: Huia.

Māori Language Advisory Group. (2015). Pūrongo ki te minita whanaketanga Māori: Te Whare o te Reo Mauriora. Retrieved from https://www. tpk.govt.nz/docs/Maori\%20Language \% 20 Advisory\%20Group\%20Final\%20Report \%20 English\%20Version.pdf

May, S. (2018). Surveying language rights: Interdisciplinary perspectives. Journal of the 
Royal Society of New Zealand, 48(2-3), 164176. http://doi.org/cvfd

Moon, P. (2018). Killing te reo Māori. Palmerston North, New Zealand: Campus Press.

Ngaha, A. (2013). Te reo Māori and Māori identity: What's in a maunga? In M. Kawharu (Ed.), Maranga mai! Te reo and marae in crisis? (pp. 71-94). Auckland, New Zealand: Auckland University Press.

Nicholson, R., \& Garland, R. (2010). New Zealanders' attitudes to the revitalisation of the Maori language. Journal of Multilingual and Multicultural Development, 12(5), 393-410. http://doi.org/ bmzbjt

Olsen-Reeder, V. (2017a). He manga wai e kore e whitikia? Ngā au ripo o te reo rua, o te iwi kōrero Māori. MAI Journal, 6(3), 245-254. http://doi. org/cvff

Olsen-Reeder, V. (2017b). Kia tomokia te kākahu o te reo Māori: He whakamahere i ngā kōwhiri reo a te reo rua Māori (Unpublished $\mathrm{PhD}$ thesis). Victoria University of Wellington, Wellington, New Zealand.

Ormsby-Teki, T., Timutimu, N., Palmer, H., Ellis, R., \& Johnston, P. (2011). Reo o te kāinga: A Ngāi Te Rangi tribal response to advancing Māori language in the home. Retrieved from http://www. maramatanga.co.nz/sites/default/files/05\%20 RF\%2014\%20Web\%20ready.pdf

Pōtiki, M. (2015). Me tā tāua mokopuna. New Zealand Journal of History, 49(1), 155-176.

Pōtiki, M. (2017). Ko hurumutu te reo: Ko te matenga o te reo ki Ōtākou. MAI Journal, 6(3), 334-343. http://doi.org/cvfg

Reedy, T. (2000). Te reo Māori: The past 20 years and looking forward. Oceanic Linguistics, 39(1), 157-168. http://doi.org/ctgsqs

Reese, E., Keegan, P., McNaughton, S., Kingi, T. K., Carr, P., Schmidt, J., . . . Morton, S. (2018). Te reo Māori: Indigenous language acquisition in the context of New Zealand English. Journal of Child Language, 45(2), 340-367. http://doi. org/gdgjzf

Spolsky, B. (Ed.) (1986). Language and education in multilingual settings. Clevedon, England: Multilingual Matters.

Spolsky, B. (2004). Language policy. Cambridge, UK: Cambridge University Press.
Spolsky, B. (2009). Language management. Cambridge, UK: Cambridge University Press. http://doi.org/ b9rhkt

Spolsky, B. (2012). Family language policy: The critical domain. Journal of Multilingual and Multicultural Development, 33(1), 3-11. http:// doi.org/fzzsmj

Statistics New Zealand. (2014). Measuring te reo Māori speakers: A guide to different data sources. Retrieved from http://archive.stats.govt.nz/ browse_for_stats/people_and_communities/ maori/measuring-te-reo-maori-speakers.aspx

Statistics New Zealand. (2017). Speakers of te reo Māori. Retrieved from http://archive.stats. govt.nz/browse_for_stats/snapshots-of-nz/ nz-progress-indicators/Home/Social/speakersof-te-reo-maori.aspx

Te Huia, A. (2017). Exploring the role of identity in Māori heritage language learner motivations. Journal of Language, Identity \& Education, 16(5), 299-312. http://doi.org/cvfh

Te Kupenga. (2014). Te Kupenga 2013 (English)—corrected. Retrieved from http://archive.stats.govt. nz/browse_for_stats/people_and_communities/ maori/TeKupenga_HOTP13/Commentary.aspx

Te Mātāwai. (2018). Our people. Retrieved from https:/www.tematawai.maori.nz/\#Our-People

Te Puni Kōkiri. (2008). The bealth of the Mãori language in 2006. Wellington, New Zealand: Author.

Te Puni Kōkiri. (2010). 2009 survey of attitudes, values and beliefs towards the Māori language. Retrieved from https://www.tpk.govt.nz/ en/a-matou-mohiotanga/language/2009-surveyof-attitudes-values-and-beliefs-toward

Te Puni Kōkiri. (2011). Te reo mauriora: Te arotakenga o te rāngai reo Māori me te rautaki reo Māori. Wellington, New Zealand: Author.

Te Puni Kōkiri. (2014). Te rautaki reo Māori: Māori language strategy. Available from: http://www. tpk.govt.nz/en/a-matou-mohiotanga/language/ maori-language-strategy-2014

UNESCO. (2017). UNESCO atlas of the world's languages in danger. Retrieved from http://www. unesco.org/languages-atlas 